\title{
Molecules in food that alter drug metabolism
}

\author{
By A. E. M. Mclean, Department of Experimental Pathology, University College \\ Hospital Medical School, London WCI $E$ 67f
}

Drugs are a sub-class of the large class of molecules which are absorbed but do not enter into the normal pathways of energy metabolism or biosynthesis. As foreign compounds are ubiquitous in food, enzyme systems have evolved for their disposal. The pathways that metabolize amines, sterols, paraffins and other molecules from food have enabled man to use and dispose of drugs as well (Williams, 1959; Parke, 1968).

It is now becoming clear that most toxic and carcinogenic molecules are a further sub-class of this class. They are those molecules which are stable enough to survive in the environment, but once inside the body happen to be converted to reactive molecules capable of attacking cell macromolecules. The activation step is usually carried out by the drug-metabolizing systems, and this is one main reason for interest in drug metabolism (McLean \& McLean, 1969; Miller, 1970; Brodie, Cho, Krishna \& Reid, 1971).

In addition, steroid hormones can be metabolized by the drug-metabolizing enzymes (often called mixed-function oxidases, hydroxylating enzymes, or microsomal cytochrome $P$-450 systems). If environmental factors alter hormone metabolism, they may alter the disease pattern of the population (Conney, Welch, Kuntzman, Chang, Jacobson, Munro-Faure, Peck, Bye, Poland, Poppers, Finster \& Wolff, 1971).

Drug metabolism is concentrated in the liver, and in particular in a triple system consisting of an uptake system ( $\mathrm{Y}$ and $\mathrm{Z}$ proteins), an oxygen insertion system centred on cytochrome $P-450$, and a conjugation system (McLean \& McLean, 1972). This triple system is in line with other proteins that are adapted to removal of foreign compounds. Albumin transports lipophilic molecules, and the biliary apparatus can secrete conjugated drugs into the bile.

Various parts of the triple system are also adaptive, in that loading the animal with substrate leads to synthesis of more enzymes. In particular, compounds that form enzyme-substrate complexes with cytochrome $P-45$ o lead to massive synthesis of the whole electron transport chain-cytochrome $P-45^{\circ}$ complex of the endoplasmic reticulum. It seems that substrates that bind onto the enzyme but are poorly metabolized, like phenobarbitone, 2,2-bis ( $p$-chlorophenyl)-1, I, I-trichloroethane (DDT) or the inhibitor SKF $525 \mathrm{~A}$, are the most powerful inducers (Paine \& McLean, 1974). 


\section{Dietary influences}

We now know that drug metabolism is profoundly influenced by genetic factors, by inducing drugs and environmental chemicals, and, in animals, by diet. The main nutrient factors are protein, unsaturated fat, and total energy intake. A host of non-nutrient inducers are present both as natural compounds, additives and contaminants. Alcohol is an inducer when given as $10 \%$ of energy intake or more. All such statements depend on measurements of drug metabolism, and many misconceptions about drug metabolism rest on an inadequate appreciation of the problems of measurement.

\section{Measurement of drug metabolism}

Drug metabolism can be measured in a number of ways, each of which is unsatisfactory on its own. Sleeping time after a standard dose of hexobarbital can be measured in the whole animal. But as soon as one deals with an unusual body composition, as in the pregnant animal, or an animal with oedema or a large tumour, one is in difficulty. Should the dose of hexobarbital be given on the basis of actual body-weight or of estimated body-weight? The plasma clearance of a drug gives a better estimate of the activity of drug-metabolizing enzymes, and is rarely used.

But when clearances are measured and several drugs are used, there is often no correlation between clearance of one drug and another (Kadar, Inaba, Endrengi, Johnson \& Kalow, 1973). Drug metabolism is not a single entity but a family of enzymatic processes. However, many factors, such as low-protein diet or phenobarbital induction, influence a whole sector of drug-metabolizing enzymes as a block. In this circumstance the amount of cytochrome $P_{-45}$ in liver homogenates can be measured to give an estimate of over-all drug oxidation ability per $g$ liver, or per liver, or per animal (McLean \& McLean, 1972; McLean \& Day, 1974). This avoids the problems of using isolated microsomes, where it is hard to know what proportion of the activity present in the liver has been recovered. In this, as in other enzyme measurements, the relation of in vitro to in vivo effects remains problematical.

In measuring the response to inducing substances such as phenobarbital, one can either give a dose that elicits the maximum response, for a time that is long enough for the new steady state to be reached, and so measure the quantity of maximal response, or else one can use a lower dose or shorter time and so measure the rate of response (Marshall \& McLean, 1969). Frequently dose and time schedules are used which give neither maximal response nor rate of response but some intermediate measure of unknown significance.

Benzo( $\alpha$ )pyrene hydroxylation is measured by an extraordinarily sensitive technique that requires only a few $\mathrm{mg}$ tissue, but indicates the activity of a highly specialized, though important, member of the family of microsomal hydroxylases rather than typical drug metabolism (Wattenberg, 197I).

\section{Purified diets and protein}

When a semi-synthetic diet is fed to rats, their rate of drug metabolism depends 
on the protein content of the diet (Kato, Chiesara \& Vassanelli, 1962; McLean \& McLean, 1966). The adaptation to low-protein diet is rapid, being complete in about $4 \mathrm{~d}$. In addition, the response to phenobarbitone is severely reduced in rats given low-protein diets (Marshall \& McLean, 1969). The rat lung is similarly responsive to the protein content of the diet, but the kidney, which responds to fat content, is not affected by low-protein diets (Paine \& McLean, 1973).

\section{Fats}

When a high-protein, purified diet containing $5^{\circ} \mathrm{g}$ olive oil $/ \mathrm{kg}$, or no fat, is given to rats, cytochrome $P-45^{\circ}$ levels are still lower than those found in rats fed on stock pellets. The response to phenobarbitone is greatly reduced. However, when a diet with $100 \mathrm{~g}$ herring $0 \mathrm{il} / \mathrm{kg}$ is given, phenobarbital-induced levels of cytochrome $P-45^{\circ}$ rise to the levels found in animals fed on stock diets (Table $\mathrm{I}$ ). This effect is not due simply to essential fatty acid deficiency, because sunflower oil is less effective than herring oil (Marshall \& McLean, 1971 $a, b$ ).

Table I. Effect of purified diets on induction by phenobarbitone of cytochrome $\mathrm{P}-45^{\circ}$ in rat liver homogenate

\begin{tabular}{|c|c|c|c|c|}
\hline \multirow{3}{*}{ Diet } & \multicolumn{4}{|c|}{$\begin{array}{c}\text { Cytochrome } P-45 \circ \text { in liver homogenate } \\
\text { (nmol/g liver) }\end{array}$} \\
\hline & \multicolumn{2}{|c|}{ Basal* } & \multicolumn{2}{|c|}{ +Phenobarbitone* } \\
\hline & Mean & SD & Mean & SD \\
\hline Stock pellets $4 \mathrm{IB} \uparrow$ & 40 & 9 & 142 & 35 \\
\hline Casein $200 \mathrm{~g} / \mathrm{kg}$; no fat & 32 & 2 & 71 & 17 \\
\hline Casein $200 \mathrm{~g} / \mathrm{kg}$; herring oil roo $\mathrm{g} / \mathrm{kg}$ & 32 & 5 & 138 & 29 \\
\hline
\end{tabular}

Experiments were carried out with linoleic acid. When a diet containing $50 \mathrm{~g}$ linoleic acid/kg is given after storage, it allows $P$ - 450 levels to rise and permits full induction by phenobarbitone. When the linoleic acid is protected from autoxidation by addition of the antioxidant butylated hydroxyanisole (BHA), then it has hardly any effect (McLean \& Marshall, I97I). It seems that fatty acid hydroperoxides or similar oxidation products play an essential role in the induction of drug-metabolizing enzymes in the liver.

\section{Other nutrients}

Nutrients other than protein and fat have minor and secondary effects. Trace elements and vitamins only alter drug metabolism minimally or under extreme conditions. For instance, the changes produced by vitamin $\mathrm{E}$ or selenium deficiency are so small as to be insignificant. 
Non-nutrients in food

The non-nutrients in food comprise both the natural and added molecules. Many naturally occurring molecules have the ability to induce microsomal oxidations, especially when sensitive assays, like that for benzopyrene hydroxylase, are used to detect the inducing effects.

Wattenberg has shown that inducers are present in many plant foods, and that both liver and gastrointestinal hydroxylases are induced. Tangeretin and many other flavones act as inducers, and there are doubtless many more natural inducers to be found (Wattenberg, 1971; Wattenberg, Page \& Leong, 1968).

Inducers present in wood shavings, animal bedding, and in commercial diets have produced profound changes in the incidence of cancer in the animals fed and bedded on them (Sabine, Horton \& Wicks, 1973).

\section{Food additives and contaminants}

In addition to the natural inducers, we have to consider the additives and contaminants in food. The commonly used antioxidants like BHA and butylated hydroxytoluene are inducers, but only at levels far above those in normal use $\left(5^{\circ} \mathrm{mg}\right.$ v. $0.2 \mathrm{mg} / \mathrm{kg}$ body-weight per d) (Gilbert \& Golberg, 1965). However, there is no evidence to show whether or not these sub-threshold doses act synergistically with natural inducers or are antagonistic.

Pesticide residues such as DDT are present at low levels in food. The concentrations in food are well below those needed to cause induction in rats (Kinoshita, Frawley \& DuBois, I966; Abbott, Collins \& Goulding, 1972). However, the body fat content of DDT found in man is close to that found in rats when induction begins $(5 \mu \mathrm{g} / \mathrm{g})$. It is possible that man lives on the threshold of induction by DDT. The polychlorinated biphenyls are among the most powerful inducers, and residues contaminating the marine environment are likely to cause drastic changes in drug metabolism in many species (Chen \& DuBois, 1973).

\section{Drug metabolism in man}

For many drugs there are multiple alternative routes of metabolism. Since some routes lead to detoxication (Williams, 1959) while others lead to toxic or carcinogenic effects, it is important to measure the rate and direction of metabolism of foreign compounds in man. So far no satisfactory method of doing this has been devised (see Vesell, 1971). The current methods usually measure the rate of metabolism of a single compound, but give no indication of the direction of drug metabolism, whether, for instance, side-chain oxidations or ring oxidations predominate.

The plasma half-life of antipyrine, and nortriptyline steady-state levels, have been used to show the powerful genetic factor in drug metabolism (Alexanderson, Price Evans \& Sjöqvist, 1969; Vesell, Passananti, Greene \& Page, 1971). Studies of identical twins in the USA and Sweden have shown that $90 \%$ of the variance inside these populations can be accounted for on a genetic basis. The antipyrine technique has also been used to show that workers in a DDT factory have an increased 
rate of drug metabolism, and that man, like other animals, responds to phenobarbitone with an increased rate of drug metabolism (Conney et al. I971; Kolmodin, Azarnoff \& Sjöqvist, 1969).

Moreover, studies in the USA, Scotland, Hannover and London (O'Malley, Crooks, Duke \& Stevenson, 197I; Vesell et al. 197r; May, Helmstaedt, Büstgens \& McLean, I974), all give the same mean and standard deviation for plasma half-life of antipyrine in man. We know that the amount of DDT and also of antioxidants such as BHA is far greater in the body fat of citizens in the USA than in the UK (Abbott et al. 1972; Collings \& Sharratt, 1970). This means that the amounts of these substances in the food have not yet reached a level where they are influencing the rate of metabolism of antipyrine.

Recent studies in human liver biopsies (Schoene, Fleischmann, Remmer \& von Oldershausen, 1972), have shown that cytochrome $P$-450 levels do not predict rates of metabolism of antipyrine, and that the correlation between quinine clearance and cytochrome $P-45 \circ$ level is around 0.5 (May et al. 1974; McLean, unpublished results). It is evident that there is no one rate-limiting step for the metabolism of all drugs.

Recent studies have shown that the metabolism of benzo( $\alpha)$ pyrene can be measured in human lymphocyte cultures, that there are genetic differences between individuals in their capacity to metabolize benzo( $\alpha)$ pyrene, and that those individuals whose lymphocytes respond to inducers with high rates of benzo( $\alpha$ )pyrene metabolism are likely to be unduly susceptible to lung cancer on exposure to cigarette smoke (Kellermann, Shaw \& Luyten-Kellermann, 1973).

It is important to know whether inter-individual susceptibility to other cancers is similarly determined. Moreover, we need to know the basis for the variation in disease patterns between populations. There is good evidence that this is related to dietary rather than genetic factors. Plasma half-life of antipyrine or any other drug is probably not a sensitive enough index: we need test substances that will tell us the direction as well as the rate of drug metabolism. We badly need methods for measuring inter-individual and inter-group differences of metabolism of foreign compounds, since only then will we be able to find out if food has any influence on drug metabolism in man.

This work has been supported by the British Nutrition Foundation.

\section{REFERENCES}

Abbott, D. C., Collins, G. B. \& Goulding, R. (1972). Br, med. F. ii, 553.

Alexanderson, B., Price Evans, D. A. \& Sjöqvist, F. (1969). Br. med. F. iv, 764 .

Brodie, B. B., Cho, A. K., Krishna, G. \& Reid, W. D. (r97 I). Ann. N.Y. Acad. Sci. r79, II.

Chen, T. S. \& DuBois, K. P. (1973). Toxic. appl. Pharmac. 26, 504.

Collings, A. J. \& Sharratt, M. (1970). Food Cosmet. Toxicol. 8, 409.

Conney, A. H., Welch, R., Kuntzman, R., Chang, R., Jacobson, M. S., Munro-Faure, A. D., Peck, A. W., Bye, A., Poland, A., Poppers, P. J., Finster, M. \& Wolf, J. A. (1971). Ann. N.Y. Acad. Sci. I79, 155 .

Gilbert, D. \& Golberg, L. (1965). Food Cosmet. Toxical. 3, 417.

Kadar, D., Inaba, T., Endrengi, L., Johnson, G. E. \& Kalow, W. (I973). Clin. Pharmac. Ther. $14,552$. Kato, R., Chiesara, E. \& Vassanelli, P. (1962). Biochem. Pharmac. 11, 2 Ir. 
Kellermann, G., Shaw, C. R. \& Luyten-Kellermann, M. (1973). New Engl. F. Med. 289, 934.

Kinoshita, F. K., Frawley, J. P. \& DuBois, K. P. (1966). Toxic. appl. Pharmac. 9, 505.

Kolmodin, B., Azarnoff, D. L. \& Sjöqvist, F. (1969): Clin. Pharmac. Ther. ro, 638.

McLean, A. E. M. \& Day, P. A. (1974). Biochem. Pharmac. 23, 1173.

McLean, A. E. M. \& McLean, E. K. (1966). Biochem. F. roo, 564.

McLean, A. E. M. \& McLean, E. K. (I969). Br. med. Bull. 25, 278.

McLean, A. E. M. \& McLean E. K. (1972). In The Therapeutic Choice in Paediatrics p.84 [W. L. Buland and B. M. Laurance, editors]. London: J. \& A. Churchill Ltd.

McLean, A. E. M. \& Marshall, W. J. (1971). Chemico-biol. Interactions 3, 294.

Marshall, W. J. \& McLean, A. E. M. (1969). Biochem. Pharmac. 18, 153.

Marshall, W. J. \& McLean, A. E. M. (197 Ia). Biochem. F. 122, 569.

Marshall, W. J. \& McLean, A. E. M. (1971b). Proc. Nutr. Soc. 30, 66A.

May, B., Helmstaedt, D., Büstgens, L. \& McLean, A. E. M. (r974). Clin. Sci. 46, I IP.

Miller, J. A. (1970). Cancer Res. 30, 559.

O'Malley, K., Crooks, J., Duke, E. \& Stevenson, I. H. (I97I). Br. med. Y. iii, 607.

Paine, A. J. \& McLean, A. E. M. (1973). Biochem. Pharmac, 22, 2875.

Paine, A. J. \& McLean, A. E. M. (1974). Biochem. Biophys. Res. Commun. 58, 482.

Parke, D. V. (1968). The Biochemistry of Foreign Compounds. Oxford: Pergamon Press.

Sabine, J. R., Horton, B. J. \& Wicks, M. W. (1973). F. natn. Cancer Inst. 50, 1237.

Schoene, B., Fleischmann, R. A., Remmer, H. \& von Oldershausen, H. F. (1972). Eur. F. Clin. Pharmac. $4,65$.

Vesell, E. S. (editor) (197r). Ann. N.Y. Acad. Sci. 179.

Vesell, E. S., Passananti, G. T., Greene, F. E. \& Page, J. G. (i971). Ann. N.Y. Acad. Sci. r79, 752.

Wattenberg, L. W. (1971). Cancer, N.Y. 28, 99.

Wattenberg, L. W., Page, M. A. \& Leong, J. L. (1968). Cancer Res. 28, 934.

Williams, R. T. (1959). Detoxication Mechanisms p. 735. London: Chapman \& Hall. 